\title{
PARTISIPASI ANGGOTA PADA KEGIATAN KELOMPOK TANI MITRA JAYA DI DESA MUNDUNG KECAMATAN TOMBATU TIMUR
}

\author{
Cindy Kartika Tulandi \\ Celcius Talumingan \\ Sherly Gladys Jocom
}

\begin{abstract}
This study aims to determine the participation of members in the Mitra Jaya farmer group activities in Mundung Village, East Tombatu District. This research took place from October to December 2018. The data used were primary data obtained through interviews using a questionnaire to 10 respondents and secondary data obtained from the Mundung Village Office in East Tombatu District. The technique of collecting data uses census techniques. Data analysis used in this study is descriptive analysis using a Likert Scale. The results showed that the participation of members in farmer groups was high, because they participated in each activity held by the Mitra Jaya farmer groups both in the activities of the planning stage, the implementation stage and the evaluation phase of farmer group activities. The participation of members in the Mitra Jaya farmer group in Mundung Village, Tombatu Timur District in the management of farmer group activities is high. ${ }^{*}{ }^{\mathrm{eprm}}{ }^{*}$.
\end{abstract}

Keywords: participation, activities, farmer group, Mundung Village, East Tombatu District.

\begin{abstract}
ABSTRAK
Penelitian ini bertujuan untuk mengetahui partisipasi anggota pada kegiatan kelompok tani Mitra Jaya di Desa Mundung, Kecamatan Tombatu Timur. Penelitian ini berlangsung dari bulan Oktober sampai bulan Desember 2018. Data yang digunakan adalah data primer yang diperoleh melalui wawancara dengan menggunakan kuesioner kepada 10 responden dan data sekunder diperoleh dari Kantor Desa Mundung Kecamatan Tombatu Timur. Teknik pengumpulan data menggunakan teknik sensus. Analisis data yang digunakan dalam penelitian ini adalah analisis deskriptif dengan menggunakan Skala Likert. Hasil penelitian menunjukkan bahwa partisipasi anggota pada kelompok tani tergolong tinggi, karena mereka ikut serta dalam setiap kegiatan yang diadakan oleh kelompok tani Mitra Jaya baik pada kegiatan tahap perencanaan, tahap pelaksanaan dan tahap evaluasi kegiatan kelompok tani. Partisipasi anggota pada kelompok tani Mitra Jaya di Desa Mundung Kecamatan Tombatu Timur pada pengelolaan kegiatan kelompok tani tergolong tinggi. "eprm*.
\end{abstract}

Kata kunci: partisipasi, kegiatan, kelompok tani, Desa Mundung, Kecamatan Tombatu Timur.

\section{PENDAHULUAN}

\section{Latar Belakang}

Indonesia merupakan negara agraris yang sebagian besar masyarakatnya berprofesi sebagai petani dengan ketersediaan lahan pertanian yang luas dan keanekaragaman hayatinya (Pane, 2017).

Sulawesi Utara memiliki tanah yang amat subur dan sangat kaya dengan hasil alamnya sehingga sangat cocok untuk bercocok tanam.
Sumber Daya Manusia yang memiliki jiwa sosial yang tinggi akan mampu meningkatkan produktivitas kelompok tani melalui partisipasi yang diberikan. Partisipasi memang bukanlah sesuatu yang baru yang kita lihat, dengar bahkan dilakukan dalam berbagai kegiatan yang bertujuan untuk membangun baik dari tingkat propinsi, kota, kelurahan maupun desa, suatu pembangunan dan pengembangan hasil pembangunan tidak akan berhasil tanpa adanya partisipasi (Pentury, 2016). 
Partisipasi anggota atau partisipasi petani merupakan keikutsertaan dari petani baik secara individu maupun secara kelompok dengan penuh kesadaran dan tanggung jawab dalm bidang usaha pertanian. Partisipasi merupakan faktor yang sangat penting dalam melaksanakan berbagai aktivitas ataupun program pertanian. Partisipasi tersebut dapat berupa partisipasi dalam tahap pembentukan keputusan, partisipasi dalam tahap pelaksanaan dan partisipasi dalam tahap evaluasi.

Kelembagaan dalam pengertian ilmu sosial tidak semata-mata lembaga atau instansi atau organisasi yang memiliki struktur saja, namun juga meliputi seperangkat tatanan norma dalam kehidupan bermasyarakat guna mencapai tujuan tertentu (Amanah, 2014). Pengertian kelembagaan juga mencakup kegiatan sistem gotong royong, sistem sakap dan bagi hasil dan sebagainya, yang merupakan aktivitas kolektif masyarakat yang memiliki kelengkapan norma atau aturan tak tertulis yang dipahami dan disepakati oleh pelakunya.

Secara umum kelompok tani dibentuk untuk memecahkan permasalahan yang dihadapi petani yang tidak bisa diatasi secara individu, kelompok tani dapat dibentuk secara swadaya maupun atas dasar kepentingan kebijakan dari pemerintah melalui Dinas Pertanian (Nuryanti, 2011).

Desa Mundung terdapat dari 6 kelompok tani yang aktif. Kelompok tani Mitra Jaya merupakan kelas lanjut dan salah satu kelompok tani yang aktif dari beberapa kelompok tani di Desa Mundung. Jumlah anggota Kelompok Tani Mitra Jaya berjumlah 10 orang. Kelompok Tani Mitra Jaya dibentuk karena awalnya ada kegiatan mapalus, sehingga anggota mengambil keputusan untuk mengembangkan kelompok tani dengan tujuan kesejahteraan kelompok tani maupun bersama. Kelompok Tani Mitra Jaya mengelola usahatani padi sawah dan kedelai dengan luas lahan sebesar $20 \mathrm{Ha}$. Kelompok Tani Mitra Jaya dibentuk pada tahun 2010 dan masih aktif sampai sekarang 2018. Kelompok Tani Mitra Jaya selalu aktif dalam kegiatan kelompoknya, hal ini dikarenakan oleh budaya mapalus atau budaya gotong royong yang sangat tinggi yang ditanamkan oleh para anggota didalam kelompok. Ketua dari kelompok tani Mitra Jaya merupakan petani yang mampu menggerakkan seluruh anggotanya untuk selalu aktif dalam berbagai kegiatan kelompok tani.

Usaha meningkatkan kesejahteraan petani dan ketahanan pangan, peran kelembagaan kelompok tani dan partisipasi anggota sangat penting dalam mendukung dan melaksanakan berbagai program yang sedang dan akan dilaksanakan oleh kelompok tani. Hal inilah yang membuat penulis tertarik untuk mengangkat judul ini, serta penulis juga ingin mencari tahu bagaimana partisipasi anggota secara spesifik pada kelompok tani Mitra Jaya karena hal tersebut merupakan pelaku utama dan pelaku usaha dalam pembangunan ketahanan pangan.

\section{Rumusan Masalah \\ Bagaimana Partisipasi Anggota dalam} Kegiatan Kelompok Tani Mitra Jaya di Desa Mundung Kecamatan Tombatu Timur?

\section{Tujuan Penelitian}

Penelitian ini bertujuan untuk mengetahui Partisipasi Anggota pada kegiatan Kelompok Tani Mitra Jaya.

\section{Manfaat Penelitian}

1. Memberikan informasi dan gambaran tentang partisipasi anggota pada Kegiatan Kelompok Tani Mitra Jaya.

2. Sebagai bahan pertimbangan bagi pemerintah dan instansi terkait untuk pengembangan kelompok tani pada umumnya.

\section{METODE PENELITIAN}

\section{Waktu dan Tempat Penelitian}

Penelitian ini dilaksanakan selama tiga bulan mulai dari bulan Oktober sampai bulan Desember 2018, mulai dari persiapan sampai dengan penyusunan laporan hasil penelitian. Tempat penelitian dilaksanakan di Desa Mundung, Kecamatan Tombatu Timur, Kabupaten Minahasa Tenggara.

\section{Jenis dan Sumber Data}

Jenis dan sumber data dalam penelitian ini sebagai berikut:

1. Data primer diperoleh melalui wawancara langsung kepada responden anggota Kelompok Tani Mitra Jaya dengan menggunakan kuesioner yang telah disiapkan.

2. Data sekunder diperoleh dari Kantor Desa Mundung Kecamatan Tombatu Timur serta instansi yang terkait dalam penelitian ini.

\section{Metode Pengambilan Sampel}

Pengambilan sampel dalam penelitian ini dilakukan dengan teknik sensus yaitu semua anggota Kelompok Tani Mitra Jaya berjumlah 10 responden, sehingga semua anggota diwawancarai dengan menggunakan kuesioner. 


\section{Konsep Pengukuran Variabel}

Pengukuran variabel dalam penelitian ini mencakup tingkat partisipasi anggota pada kegiatan kelompok tani, yaitu:

\section{Karakteristik Responden}

1. Nama

2. Jenis Kelamin (L/P)

3. Umur, dalam satuan tahun.

4. Tingkat Pendidikan, diukur menurut tingkat pendidikan yang ditamatkan.

\section{Indikator Partisipasi Responden}

A. Partisipasi dalam tahap perencanaan:

1. Keaktifan dalam mengikuti pertemuan.

1) Sangat Aktif (17-24 kali dalam setahun)

2) Aktif (9-16 kali dalam setahun)

3) Kurang Aktif (1-8 kali dalam setahun)

2. Keaktifan dalam memberikan masukan pada saat pertemuan.

1) Sangat Aktif (17-24 kali dalam setahun)

2) Aktif (9-16 kali dalam setahun)

3) Kurang Aktif (1-8 kali dalam setahun)

B. Partisipasi dalam tahap pelaksanaan:

3. Keaktifan dalam penanaman padi sawah.

1) Sangat Aktif (2 kali dalam setahun)

2) Aktif (1 kali dalam setahun)

3) Tidak Aktif (0 kali dalam setahun)

4. Keaktifan dalam penanaman Kedelai.

1) Sangat Aktif (2 kali dalam setahun)

2) Aktif (1 kali dalam setahun)

3) Tidak Aktif (0 kali dalam setahun)

5. Keaktifan dalam panen dan pasca panen padi sawah.

1) Sangat Aktif (2 kali dalam setahun)

2) Aktif (1 kali dalam setahun)

3) Tidak Aktif (0 kali dalam setahun)

6. Keaktifan dalam panen dan pasca panen kedelai.
1) Sangat Aktif (2 kali panen dalam setahun)
2) Aktif (1 kali panen dalam setahun)
3) Tidak Aktif (0 kali panen dalam setahun)

7. Keaktifan dalam mengikuti penyuluhan.

1) Sangat Aktif (2-4 kali dalam setahun)

2) Aktif (2 kali dalam setahun)

3) Kurang Aktif (1 kali saja dalam setahun)

8. Keaktifan dalam memberikan iuran wajib.

1) Sangat Aktif (17-24 dalam setahun)

2) Aktif (9-16 dalam setahun)

3) Kurang Aktif (1-8 kali saja dalam setahun)

C. Partisipasi dalam tahap evaluasi:

9. Keterlibatan dalam penentuan kegiatan kelompok.
1) Sangat Aktif (setiap hasil kegiatan kelompok selalu memberikan masukan dalam hasil yang diperoleh).

2) Aktif (hampir disetiap kegiatan kelompok selalu memberikan masukan).

3) Kurang Aktif (jarang memperhatikan dan memberikan masukan mengenai kegiatan kelompok)

10. Keterlibatan dalam mengukur berbagai hasil kegiatan usaha tani.

1) Sangat Aktif (setiap hasil kegiatan usaha tani selalu memberikan masukan dalam hasil yang diperoleh).

2) Aktif (hampir di setiap hasil kegiatan usaha tani selalu memberikan masukan).

3) Kurang Aktif (jarang memperhatikan dan memberikan masukan mengenai berbagai hasil kegiatan usaha tani).

\section{Analisis Data}

Analisis data yang digunakan dalam penelitian ini adalah analisis deskriptif dengan menggunakan Skala Likert, Skala Likert digunakan untuk mengukur partisipasi seseorang atau kelompok dalam skala likert, maka variabel yang diukur dijabarkan menjadi indikator variabel. Kemudian indikator tersebut dijadikan sebagai titik tolak untuk menyusun item-item instrument yang dapat berupa pertanyaan-pertanyaan. Dalam penelitian ini disusun 10 (sepuluh) pertanyaan dengan total responden 10 (sepuluh) orang. Jawaban setiap instrument yang menggunakan skala likert diungkapkan dengan kata-kata berikut:

$$
\begin{aligned}
& \text { S3 }=\text { Sangat Aktif } \\
& \text { S2 }=\text { Aktif } \\
& \text { S1 }=\text { Kurang Aktif }
\end{aligned}
$$

Dengan cara perhitungan skor masing-masing pertanyaan:

Jumlah skor tiap kriteria = capaian skor $\mathrm{x}$ jumlah responden.

$$
\begin{aligned}
& \mathrm{S} 3=3 \mathrm{X} 10=30 \\
& \mathrm{~S} 2=2 \mathrm{X} 10=20 \\
& \mathrm{~S} 1=1 \mathrm{X} 10=10
\end{aligned}
$$

Jumlah skor ideal untuk setiap pernyataan (skor tertinggi) $=30$

Jumlah skor rendah $=20$

Dengan interpretasi nilai:

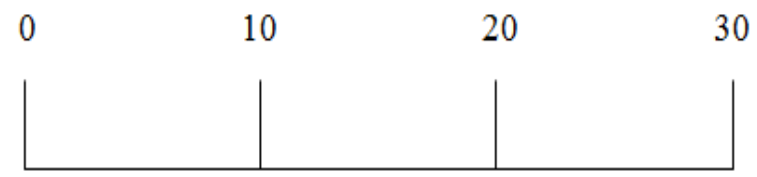

Rendah Cukup Tinggi 
Cara perhitungan skor keseluruhan untuk mengetahui partisipasi anggota:

Jumlah skor seluruh kriterium = capaian jumlah skor $\mathrm{x}$ jumlah responden $\mathrm{x}$ instrumen pertanyaan

Untuk:

$$
\begin{aligned}
& S 3=3 \times 10 \times 10=300 \\
& S 2=2 \times 10 \times 10=200 \\
& S 1=1 \times 10 \times 10=100
\end{aligned}
$$

Jumlah skor ideal untuk keseluruhan pertanyaan $=300$ (Tinggi)

Jumlah skor rendah = 100 (Rendah)

Untuk

$$
\begin{aligned}
& S 3=3 \times 10 \times 10=300 \\
& S 2=2 \times 10 \times 10=200 \\
& S 1=1 \times 10 \times 10=100
\end{aligned}
$$

Jumlah skor ideal untuk keseluruhan pertanyaan $=300$ (tertinggi)

Jumlah skor rendah $=100$ (terendah)
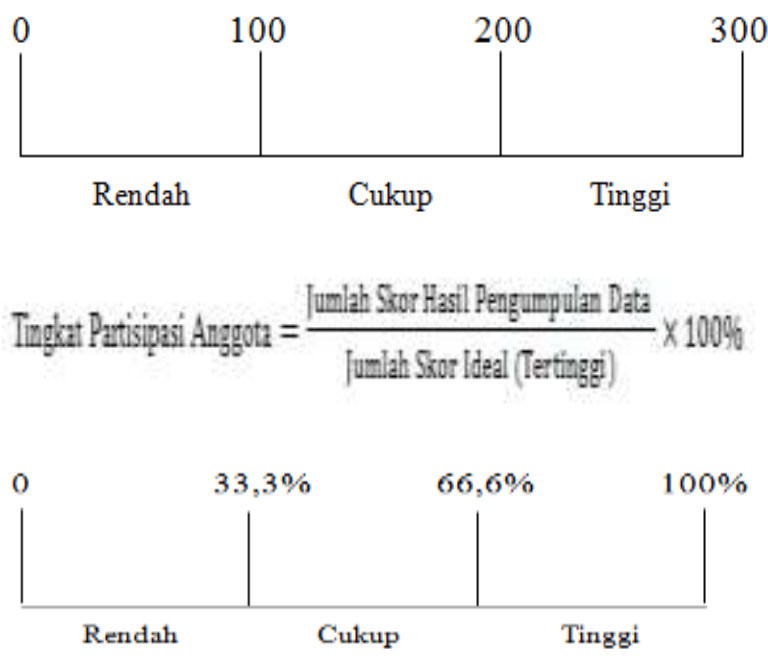

Dengan Interprestasi nilai :

Keterangan criteria Interprestasi skor partisipasi anggota:

Angka 0\%-33,3\% = Rendah

Angka 33,4\% - 66,6\% = Cukup

Angka 66,7\% - 100\% = Tinggi

\section{HASIL DAN PEMBAHASAN}

\section{Deskripsi Wilayah Penelitian}

\section{Letak Geografi dan Iklim}

Desa Mundung merupakan salah satu Desa yang terletak di Kecamatan Tombatu Timur dengan luas wilayah 300 ha yang terdiri dari 5 (lima) jaga. Adapun batas-batas jaga yaitu sebagai berikut:
1. Sebelah Utara
: Desa Winorangian
2. Sebelah Selatan
: Desa Esandom Satu
3. Sebelah Timur
: Desa Molompar Dua
4. Sebelah Barat
: Desa Mundung Satu

Secara Topografi letak Desa Mundung yaitu dengan ketinggian $300 \mathrm{M}$ dari permukaan laut, dengan kemiringan $60 \%$.

\section{Keadaan Penduduk}

Total keseluruhan jumlah penduduk yang ada di Desa Mundung sebanyak 1276 jiwa. Tabel 1 menunjukkan jumlah penduduk yang ada di Desa Mundung.

Tabel 1. Jumlah Penduduk Menurut Jenis Kelamin

\begin{tabular}{clcc}
\hline No. & Jenis Kelamin & $\begin{array}{c}\text { Jumlah Penduduk } \\
\text { (Orang) }\end{array}$ & $\begin{array}{c}\text { Persentase } \\
(\%)\end{array}$ \\
\hline 1. & Laki-laki & 680 & 51.00 \\
2. & Perempuan & 645 & 49.00 \\
\hline & Jumlah & 1.325 & 100 \\
\hline
\end{tabular}

Sumber: Kantor Desa Mundung, 2018

Tabel 1 menunjukkan jumlah penduduk berjenis kelamin laki-laki sebanyak 680 jiwa atau 51.00 persen dan jumlah penduduk berjenis kelamin perempuan sebanyak 645 jiwa atau 49.00 persen, yang tersebar dalam 5 (lima) jaga.

\section{Jumlah Penduduk Menurut Tingkat Pendidikan}

Tingkat pendidikan di Desa Mundung bervariasi mulai dari yang tidak tamat Sekolah Dasar (SD) 399 orang, tamat Sekolah Dasar (SD) 300 orang, Sekolah Lanjutan Tingkat Pertama (SLTP) 180 orang, Sekolah Lanjut Tingkat Atas (SLTA) 383 orang, tamat perguruan tinggi Strata Satu (S1) 63 orang.

\begin{tabular}{clcc}
\multicolumn{4}{c}{ Tabel 2. Jumlah Penduduk Berdasarkan Tingkat Pendidikan } \\
\hline No. & Tingkat Pendidikan & Jumlah (Orang) & Persentase (\%) \\
\hline 1. & Belum Tamat SD & 399 & 30.11 \\
2. & Tamat SD & 300 & 22.64 \\
3. & SLTP & 180 & 13.58 \\
4. & SLTA & 383 & 28.90 \\
5. & Perguruan Tinggi & 63 & 4.77 \\
\hline & Jumlah & 1.325 & 100 \\
\hline
\end{tabular}

Sumber: Kantor Desa Mundung, 2018

Tabel 2 menunjukkan bahwa yang tidak tamat SD sebanyak 399 orang atau 30,11\%, tamat SD sebanyak 300 orang atau 22,64\%, SLTP sebanyak 180 orang atau $13,58 \%$, SLTA sebanyak 383 orang atau 28,90\%, dan Perguruan Tinggi sebanyak 63 orang atau $4,77 \%$.

\section{Deskripsi Kelompok Tani Mitra Jaya}

\section{Sejarah Singkat Terbentuknya Kelompok Tani Mitra Jaya}

Kelompok Tani Mitra Jaya berdiri pada tahun 2010. Kelompok Tani Mitra Jaya dibentuk karena awalnya ada kegiatan mapalus, sehingga anggota mengambil keputusan untuk mengembangkan kelompok tani dengan tujuan kesejahteraan kelompok tani maupun bersama. Kelompok Tani Mitra Jaya sampai saat ini bukan hanya mengandalkan komoditi Padi Sawah dan Kedelai. 
Kelompok tani Mitra Jaya yang bertujuan untuk meningkatkan kemampuan yang dimiliki oleh setiap anggotanya ini merupakan kegiatan pembelajaran yang bertujuan agar para anggota mampu mengorganisasikan diri mereka sendiri agar bisa hidup lebih sejahtera.

Berdasarkan hasil penelitian partisipasi kelompok tani Mitra Jaya Desa Mundung, ada tiga aspek sebagai berikut:

a) Sarana dan Prasarana

Mengenai sarana pertanian yang ada di kelompok tani Mitra Jaya Desa Mundung, berdasarkan hasil pengamatan yaitu luas lahan pertanian Sawah dan Kedelai 20 Ha. Sarana berupa alat-alat pertanian yang dimiliki oleh kelompok tani Mitra Jaya seperti, Traktor, Semprot Padi, Rontok Padi dan Terpal Jemur. Sistem pertanian masih banyak menggunakan sistem bertani yang tradisional.

b) Permodalan

Permodalan dalam pertanian menjadi suatu faktor produksi penting dalam usaha pertanian. Sayangnya, akses petani terhadap sumber-sumber permodalan yang disediakan masih sangat terbatas. Berdasarkan hasil wawancara terhadap beberapa anggota, bahwa sebagian besar usaha pertanian yang dilakukan petani masih mengandalkan modal sendiri yang berasal dari aset pertanian yang didapat sendiri. Hasil temuan penelitian bahwa kelompok tani Mitra Jaya pada tahun 2010 mendapat bantuan dana dari dinas pertanian yang disalurkan sebesar Rp.3.000.000,- yang digunakan untuk pengembangan pengolahan sawah.

c) Pendidikan

Dengan rendahnya tingkat pendidikan petani dapat mempengaruhi randahnya kemampuan dan semangat kerja anggota. Anggota kelompok tani Mitra Jaya lebih banyak merupakan petani tradisional. Artinya petani tersebut hanya berpikiran untuk mengolah hasil pertanian dari perkebunan mereka sendiri untuk mencukupi kebutuhan saja.

d) Memperkuat Daya dan Potensi

Dari hasil penelitian yang didapat bahwa kelompok tani Mitra Jaya, bahwa kelompok tani ini banyak mendapat bantuan berupa alat-alat atau kebutuhan lainnya yang diperlukan kelompok tani dalam usaha pertanian untuk meningkatkan potensi anggotanya yang masih kurang. Adapun yang dilakukan kelompok tani dalam mengembangkan daya dan potensi anggotanya dengan mendorong anggotanya untuk rajin dan selalu mengelola lahan perkembunan kelompok atau lahan milik sendiri. Bukan hanya itu saja, tetapi melalui program usaha pengolahan hasil yaitu mencari dan belajar tentang strategi pengolahan hasil pertanian yang didapat dan diajarkan pada saat mengikuti penyuluhan dari Penyuluh Pertanian Lapangan (PPL).

\section{Anggaran Dasar (AD) Kelompok Tani Mitra} Jaya

a. Kegiatan, pemanfaatan lahan usaha dengan menerapkan usaha supaya konservasi tanah dan air sekaligus meningkatkan produksi pertanian yaitu: Pemanfaatan lahan kering, pemanfaatan lahan pertanian, meningkatkan produksi pertanian. Adapun mengembangkan usaha pertanian sistem terpadu dan mengembangkan usaha bersama yang memberikan manfaat dan meningkatkan ekonomi.

b. Keuangan Kelompok Tani "Mitra Jaya" yang menjadi anggaran dasar kelompok tani bersumber dari sumbangan dari pemerintah dan usaha lain yang dilakukan kelompok tani "Mitra Jaya" baik inisiatif dari dalam Kelompok Tani "Mitra Jaya".

c. Masa Berlaku Kelompok Tani, Kelompok tani "Mitra Jaya" terbatas paling sedikit sebanyak 1/3 dari jumlah awal anggota kelompok tani "Mitra Jaya" dan harus diadakan rapat anggota untuk maksud pembentukan kelompok tani yang baru.

\section{Anggaran Rumah Tangga (ART) Kelompok Tani Mitra Jaya}

a. Keanggotaan

Setiap pendaftar baru dapat menjadi anggota kelompok tani "Mitra Jaya" atas persetujuan ketua kelompok tani secara tertulis dapat memenuhi semua persyaratan menjadi anggota dan memenuhi semua peraturan dalam kelompok tani "Mitra Jaya". Setiap anggota kelompok tani "Mitra Jaya" wajib menggarap lahan pertanian. Syarat menjadi anggota kelompok tani "Mitra Jaya" membayar uang pendaftaran satu kali saat mendaftar dan iuran wajib setiap satu bulan dua kali pertemuan.

b. Sanksi

Setiap pelanggaran anggota kelompok tani "Mitra Jaya" yang dilakukan oleh setiap orang anggota, akan dikeluarkan dari keanggotaan secara tidak hormat dan akan kehilangan semua haknya sebagai anggota.

c. Simpanan Kelompok Tani "Mitra Jaya"

Yang menjadi simpanan kelompok tani "Mitra Jaya" adalah uang pendaftaran (yang dibayar sekali saat mendaftar menjadi anggota), uang iuran wajib (yang dibayar dalam sebulan dua kali sesuai pertemuan), dan sisa hasil usaha yang dilakukan kelompok tani "Mitra Jaya". Setiap anggota kelompok tani "Mitra Jaya" berhak memilih kekayaan kelompok tani dibagi rata dengan jumlah keseluruhan anggota. Pemasukan dan pengeluaran keuangan kelompok tani "Mitra Jaya"wajib dicatat dan dipertanggungjawabkan dalam laporan pertanggung jawaban pengurus. 


\section{Karakteristik Responden}

\section{Umur Responden}

Kemampuan bekerja atau melakukan aktifitas secara fisik bahkan cara berpikir seseorang sangat dipengaruhi faktor umur. Demikian juga dengan para petani dalam melakukan pekerjaannya, anggota yang memiliki umur muda tentunya memiliki kondisi fisik yang lebih kuat serta memiliki daya berpikir yang lebih kreatif dibandingkan yang berumur tua. Dari data primer yang diperoleh, usia anggota antara 27 sampai 60 tahun. Komposisi umur responden dalam penelitian ini disajikan pada Tabel 3.

Tabel 3. Distribusi Responden Menurut Umur Anggota Kelompok Tani Mitra Jaya

\begin{tabular}{cccc}
\hline No & Umur & $\begin{array}{c}\text { JumlahResponden } \\
\text { (Orang) }\end{array}$ & $\begin{array}{c}\text { Persentase } \\
(\%)\end{array}$ \\
\hline 1. & $20-30$ & 1 & 10.00 \\
2. & $31-40$ & 1 & 10.00 \\
3. & $41-50$ & 5 & 50.00 \\
4. & $51-60$ & 3 & 30.00 \\
\hline & Jumlah & 10 & 100 \\
\hline
\end{tabular}

Sumber: Diolah dari data primer, 2018

Tabel 3 menunjukkan bahwa jumlah responden pada umur 20-30 tahun menunjukkan paling sedikit $10 \%$, selanjutnya berada pada usia 31 40 tahun juga menunjukkan paling sedikit $10 \%$, pada usia 41-50 tahun menunjukkan persentase sebanyak 50\%, pada usia 51-60 tahun menunjukkan $30 \%$.

\section{Jumlah Responden Menurut Jenis Kelamin}

Tabel 4. Distribusi Responden Berdasarkan Jenis Kelamin Anggota Kelompok Tani Mitra Jaya

\begin{tabular}{lccc}
\hline No & $\begin{array}{c}\text { Jenis } \\
\text { Kelamin }\end{array}$ & $\begin{array}{c}\text { Jumlah Responden } \\
\text { (Orang) }\end{array}$ & Persentase (\%) \\
\hline 1. & Laki-laki & 8 & 80.00 \\
2. & Perempuan & 2 & 20.00 \\
\hline & Jumlah & 10 & 100 \\
\hline
\end{tabular}

Sumber: Diolah dari data primer, 2018

Tabel 4 menunjukkan bahwa jumlah responden yang berjenis kelamin laki-laki lebih banyak dibandingkan perempuan dengan persentase laki-laki sebanyak $80 \%$ dan responden yang berjenis kelamin perempuan menunjukkan persentase sebanyak $20 \%$.

\section{Jumlah Responden Menurut Tingkat Pendidikan}

Peranan pendidikan formal sangat penting dalam usaha peningkatan kualitas seseorang karena berguna dalam pembangunan pribadi serta peningkatan intelektual dan wawasan seseorang. Berdasarkan hasil penelitian, tingkat pendidikan responden tidak bervariasi hanya mulai dari Sekolah
Menengah Pertama (SMP) dan Sekolah Menengah Atas (SMA)/sederajat. Komposisi tingkat pendidikan responden dalam penelitian ini dapat dilihat pada Tabel 5 .

Tabel 5. Distribusi Responden menurut Tingkat Pendidikan Anggota Kelompok Tani Mitra Jaya

\begin{tabular}{clcc}
\hline No & Pendidikan & $\begin{array}{c}\text { Jumlah Responden } \\
\text { (Orang) }\end{array}$ & $\begin{array}{c}\text { Persentase } \\
(\%)\end{array}$ \\
\hline 1. & SD & - & - \\
2. & SMP & 5 & 50.00 \\
3. & SMA & 5 & 50.00 \\
\hline & Jumlah & 10 & 100 \\
\hline
\end{tabular}

Sumber: Diolah dari data primer, 2018

Tabel 5 menunjukkan distribusi responden menurut tingkat pendidikan SD tidak ada, SMP sebanyak $50 \%$, SMA sebanyak $50 \%$.

\section{Partisipasi Anggota Pada Kelompok Tani Mitra Jaya \\ Partisipasi Anggota Pada Tahap Perencanaan Keputusan}

Partisipasi pembentukan keputusan pada anggota kelompok tani Mitra Jaya dengan mengadakan pertemuan yang dilaksanakan pada hari sabtu setiap sebulan 2 kali yang mengharuskan seluruh anggota kelompok tani hadir agar kesepakatan yang ingin dicapai dapat tercapai dengan pengambilan keputusan secara mufakat. Partisipasi dalam bentuk keaktifan anggota dalam mengikuti pertemuan sudah cukup baik dengan melibatkan seluruh anggota dalam setiap kegiatan pengambilan keputusan. Perencanaan kegiatan yang biasanya dilakukan anggota yaitu merencanakan kegiatan penanaman padi, mulai dari penanaman hingga panen dan pasca panen, tidak hanya penanaman padi sawah tetapi juga penanaman kedelai. Selain itu pengambilan keputusan dalam kelompok tani Mitra Jaya juga dilakukan untuk mencari solusi dari berbagai masalah pertanian yang dihadapi dengan musyawarah yang dilakukan oleh seluruh anggota kelompok tani Mitra Jaya.

a. Keaktifan dalam Mengikuti Pertemuan

Keaktifan dalam hal ini adalah seberapa sering anggota terlibat dalam mengikuti pertemuan kelompok yang dilaksanakan setiap hari sabtu. Dalam penelitian ini keaktifan dalam mengikuti pertemuan di ukur selama satu bulan dua kali dalam satu tahun membahas mengenai berbagai kegiatan kelompok tani dimana anggota harus melaksanakan penanaman padi sawah dan penanaman kedelai, pelaksanaan penanaman secara mapalus atau gotong royong. Seluruh anggota bertanggung jawab dalam pelaksanaannya mulai dari persiapan lahan, perawatan tanaman sampai dengan panen hingga pasca panen padi sawah dan kedelai. Keaktifan dalam mengikuti pertemuan dapat dilihat pada Tabel 6 . 
Tabel 6. Kealtifan dalam Mengikuti Pertemuan

\begin{tabular}{|c|c|c|c|c|c|}
\hline No & $\begin{array}{c}\text { Tingkat } \\
\text { Pantisipasi }\end{array}$ & $\begin{array}{l}\text { Altenunife } \\
\text { Skot }\end{array}$ & $\begin{array}{l}\text { Jumlati Responden } \\
\text { (Otass) }\end{array}$ & $\begin{array}{c}\text { Persentase } \\
\text { (\%) }\end{array}$ & $\begin{array}{l}\text { Total } \\
\text { skot }\end{array}$ \\
\hline 1 & Sangat Aktif & 3 & 5 & 5000 & 15 \\
\hline 2 & Aletif & 2 & 3 & 30.00 & 6 \\
\hline 3 & Kurng Aktif & 1 & 2 & 20.00 & 2 \\
\hline & Jumlah & & 10 & 100 & 23 \\
\hline
\end{tabular}

Hasil penelitian ini menunjukkan bahwa 50\% memilih Sangat Aktif, anggota yang memilih sangat aktif adalah anggota yang sadar akan statusnya sebagai pengurus kelompok, anggota yang menginginkan terciptanya kekompakkan sesama anggota kelompok dalam melaksanakan kegiatan pertanian, 30\% memilih aktif adalah anggota yang mengikuti pertemuan agar memahami dan mengetahui hal-hal yang harus dilakukan dalam penanaman padi sawah dan kedelai, 20\% memilih kurang aktif dalam mengikuti pertemuan, hal ini dikarenakan berbagai kesibukan. Total skor yang diperoleh dari 10 responden pada pertanyaan nomor 1 adalah 23. Angka indeks partisipasi mengenai pertanyaan nomor 2 yaitu: $23 / 30 \times 100=76,6 \%$ sehingga interpretasi nilainya tergolong tinggi. Karena banyak anggota yang terlibat dalam mengikuti pertemuan setiap hari Sabtu.

b. Keterlibatan dalam Memberikan Masukan

Keaktifan dalam hal ini adalah seberapa sering anggota terlibat dalam memberikan masukan pada pertemuan yang dilaksanakan setiap hari sabtu. Dalam penelitian tentang keaktifan dalam memberikan masukan di ukur selama 1 bulan, keaktifan dalam memberikan masukan dapat dilihat dari Tabel 7.

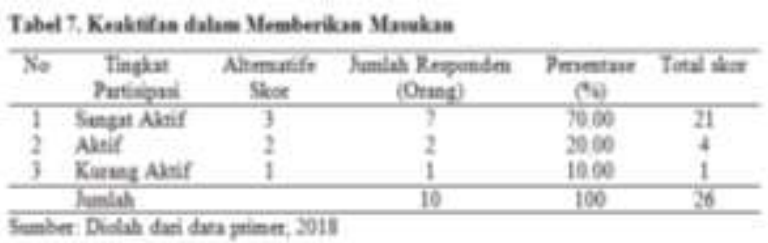

Hasil penelitian ini menunjukkan bahwa $70 \%$ memilih sangat aktif, anggota yang memilih aktif adalah anggota yang sangat aktif memberikan masukan dalam bentuk pengurusan kelompok, memberi saran dalam hal kehadiran pertemuan kelompok dan saran untuk perkembangan kelompok, 20\% memilih aktif, anggota yang memilih aktif adalah anggota yang memberikan masukan tentang keaktifan anggota dalam kegiatan-kegiatan kelompok, $10 \%$ memilih kurang aktif hal ini dikarenakan anggota kurang memberikan masukan. Total skor yang diperoleh dari 10 responden pada pertanyaan nomor 2 adalah 26. Angka indeks partisipasi mengenai pertanyaan nomor 2 yaitu: $26 / 30 \times 100=86,6 \%$ sehingga interpretasi nilainya tergolong tinggi. Karena pada saat pertemuan banyak anggota yang sangat aktif dan aktif dalam memberikan masukan.

\section{Partisipasi Anggota Pada Tahap Pelaksanaan Kegiatan Kelompok}

Partisipasi pelaksanaan kegiatan kelompok tani Mitra Jaya diikuti oleh anggota kelompok tani Mitra Jaya dengan aktif. Kegiatan kelompok tani Mitra Jaya yang dilaksanakan secara umum yaitu kegiatan penanaman padi sawah yang dilaksanakan selam 1 sampai 2 kali musim penanaman dalam setahun, penanaman kedelai yang dilakukan 1 sampai 2 kali penanaman dalam setahun, begitu juga dengan kegiatan panen dan pasca panen padi sawah yang dilaksanakan selama 1 sampai 2 kalidalam setahun, kegiatan panen dan pasca panen kedelai yang dilaksanakan 1 sampai 2 kali panen dalam setahun, kegiatan penyuluhan yang didampingi oleh Penyuluh Pertanian Lapangan yang selama setahun 4 kali dilaksanakan penyuluhan dalam setahun, karena penyuluhan dilaksanakan sesuai dalam kegiatan penanaman, kegiatan dalam memberikan iuran wajib yang pengumpulannya dilakukan 1 sampai 2 kali dalam sebulan. Dalam penelitian partisipasi dalam tahap pelaksanaan yaitu, keaktifan dalam kegiatan penanaman padi sawah, keaktifan dalam penanaman kedelai, keaktifan dalam panen dan pasca panen padi sawah, keaktifan dalam panen dan pasca panen kedelai, keaktifan dalam mengikuti penyuluhan dan keaktifan dalam memberikan iuran wajib

c. Keaktifan dalam Kegiatan Penanaman Padi Sawah

Keaktifan dalam kegiatan penanaman padi sawah adalah seberapa sering anggota terlibat dalam tahap penanaman, dalam hal ini bukan hanya penanaman tetapi juga terlibat dalam pemeliharaan padi sawah, dalam penelitian ini keaktifan di ukur selama 2 musim penanaman dalam setahun, keaktifan dalam kegiatan penanaman padi sawah dapat dilihat pada Tabel 8 .

\begin{tabular}{|c|c|c|c|c|c|}
\hline $\mathrm{Ne}_{\mathrm{e}}$ & $\begin{array}{l}\text { Inglat } \\
\text { Pantiegpes }\end{array}$ & $\begin{array}{c}\text { Atematife } \\
\text { ind }\end{array}$ & $\begin{array}{l}\text { Innlah Respenden } \\
\text { (Orang) }\end{array}$ & $\begin{array}{l}\text { Penentase } \\
\text { (Ni) }\end{array}$ & $\begin{array}{l}\text { Tetal } \\
\text { war }\end{array}$ \\
\hline 1 & Sangat Alaif & 3 & 8 & $8 \infty \infty$ & 24 \\
\hline 2 & Altif & 2 & 1 & 1000 & 2 \\
\hline \multirow[t]{2}{*}{3} & Thdil Alrif & 1 & 1 & 1000 & 1 \\
\hline & humlah & & 10 & 100 & 27 \\
\hline
\end{tabular}

Hasil penelitian ini menunjukkan bahwa $80 \%$ memilih sangat aktif adalah anggota yang ingin meningkatkan pendapatan, $10 \%$ memilih aktif adalah anggota yang berpengalaman dalam bertani, $10 \%$ memilih tidak aktif adalah anggota yang memiliki berbagai kesibukan. Total skor yang diperoleh dari 10 responden pada pertanyaan nomor 5 adalah 27. Angka indeks partisipasi mengenai pertanyaan nomor 5 yaitu: $27 / 30 \times 100=90,0 \%$ sehingga interpretasi nilainya tergolong tinggi. Karena anggota sangat aktif dalam kegiatan padi sawah. 


\section{d. Keaktifan dalam Penanaman Kedelai}

Keaktifan dalam kegiatan penanaman kedelai adalah seberapa sering anggota terlibat dalam penanaman kedelai, bukan hanya penanaman saja tetapi juga terlibat dalam merawat tanaman sampai dengan panen hingga pasca panen, dalam penelitian ini keaktifan di ukur sebanyak 1 sampai 2 kali penanaman dalam setahun, keaktifan dalam penanaman kedelai dapat dilihat dari Tabel 9.

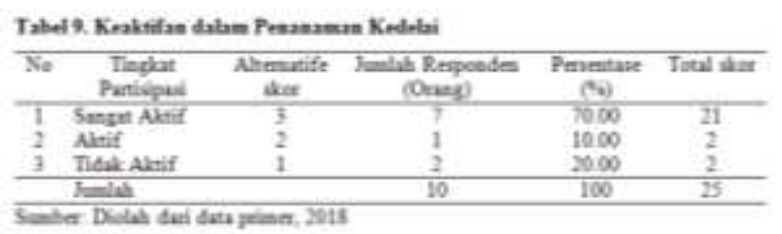

Hasil penelitian ini menunjukkan bahwa $70 \%$ memilih sangat aktif adalah anggota yang ingin meningkatkan pendapatan, $10 \%$ memilih aktif adalah anggota yang berpengalaman dalam bertani, 20\% memilih tidak aktif adalah mereka yang memiliki berbagai kesibukan. Total skor yang diperoleh dari 10 responden pada pertanyaan nomor 4 adalah 25. Angka indeks partisipasi mengenai pertanyaan nomor 4 yaitu: 25/30x $100=83,3 \%$ sehingga interpretasi nilainya tergolong tinggi. Karena anggota sangat aktif dalam kegiatan penanaman kedelai.

e. Keaktifan dalam Panen hingga Pasca Panen Padi Sawah

Keaktifan dalam panen hingga pasca panen padi sawah adalah seberapa sering anggota terlibat dalam tahap panen hingga pasca panen padi sawah, pelaksanaan kegiatan panen hingga pasca panen padi sawah dalam penelitian ini di ukur sebanyak 1 sampai 2 kali penanaman selama setahun untuk padi sawah yang sudah di panen dari lahan setiap anggota kemudian disisihkan $10 \%$ hasil padi sawah dari tiaptiap anggota untuk dipasarkan ke pasar tradisional. Keaktifan dalam panen dan pasca panen padi sawah dapat dilihat pada Tabel 10.

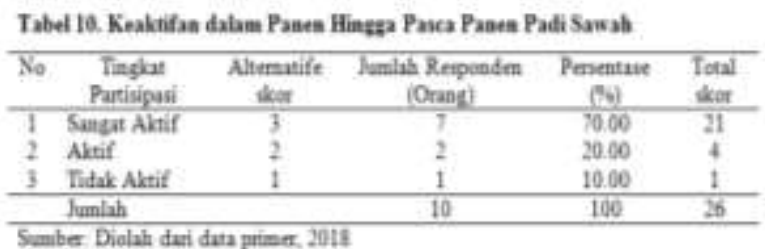

Hasil penelitian ini menunjukkan bahwa $70 \%$ memilih sangat aktif adalah anggota yang bersemangat dalam kegiatan pemanenan dan memiliki kesadaran sebagai pengurus kelompok, $20 \%$ memilih aktif adalah anggota ingin melancarkan kegiatan pertanian, 10\% memilih tidak aktif adalah anggota yang terhambat dengan kegiatan lainnya. Total skor yang diperoleh dari 10 responden pada pertanyaan nomor 5 adalah 26 . Angka indeks partisipasi mengenai pertanyaan nomor 5 yaitu: $26 / 30$ x $100=86,6 \%$ sehingga interpretasi nilainya tergolong tinggi. Karena anggota sangat aktif setiap panen hingga pasca panen padi sawah.

f. Keaktifan dalam Panen hingga Pasca Panen Kedelai

Keaktifan dalam hal ini adalah seberapa sering anggota terlibat dalam kegiatan panen hingga pasca panen kedelai, dalam penelitian ini keaktifan dalam panen dan pasca panen di ukur sebanyak 1 sampai 2 kali pemanenan dalam setahun. Keaktifan dalam panen dan pasca panen kedelai dapat dilihat pada Tabel 11 .

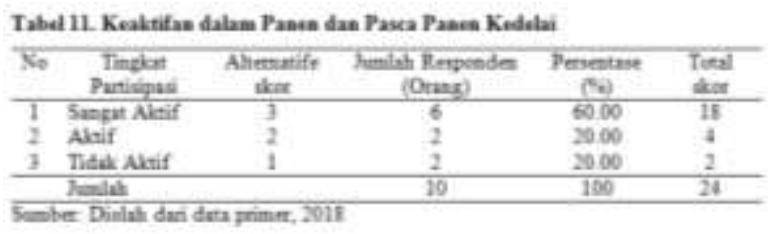

Hasil penelitian ini menunjukkan bahwa $60 \%$ memilih sangat aktif adalah anggota yang ingin menambah penghasilan, memperlancar kegiatan kelompok, 20\% memilih aktif adalah anggota yang ingin melancarkan kegiatan pertanian, 20\% memilih tidak aktif karena berbagai kesibukan lainnya. Total skor yang diperoleh dari 10 responden pada pertanyaan no 6 adalah 24. Angka indeks partisipasi mengenai pertanyaan nomor 6 yaitu: $24 / 30 \times 100=$ $80,0 \%$. Karena pada saat panen hingga pasca panen tanaman kedelai anggota sangat aktif dalam pelaksanaannya.

g. Keaktifan dalam Mengikuti Penyuluhan

Keaktifan dalam hal ini adalah seberapa sering anggota terlibat dalam mengikuti penyuluhan mengenai penyuluhan penanaman padi sawah dan kedelai, penyuluhan dilaksanakan sesuai kegiatan penanaman padi sawah dan kedelai. penyuluhan merawat tanaman padi sawah dan tanaman kedelai, penyuluhan panen hingga pasca panen padi sawah dan kedelai, penyuluhan dilaksanakan sesuai anggota kelompok tani dalam kegiatan panen hingga pasca panen yang dilaksanakan 4 kalidalam setahun yang didampingi oleh Penyuluh Pertanian Lapangan (PPL) Desa Mundung. Dalam penelitian ini keaktifan dalam mengikuti penyuluhan yang didampingi PPL di ukur selama setahun. Keaktifan dalam mengikuti penyuluhan dapat dilihat pada Tabel 12.

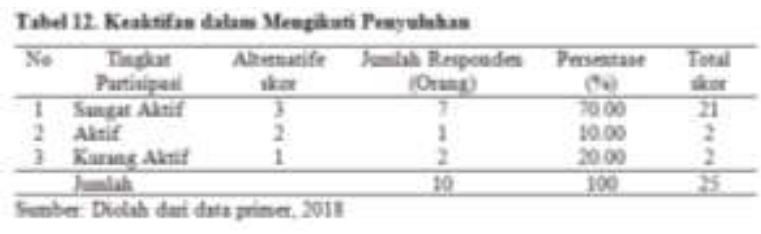


Hasil penelitian ini menunjukkan bahwa $70 \%$ memilih sangat aktif adalah anggota yang selalu hadir pada saat dilaksanakan penyuluhan dan anggota mengikuti penyuluhan agar dapat mengetahui apa saja yang akan dilakukan dalam usahatani, $10 \%$ memilih aktif adalah anggota yang mengikuti penyuluhan untuk menunjang berbagai kegiatan kelompok tani, 20\% memilih kurang aktif adalah anggota yang kurang hadir dalam penyuluhan dikarenakan berbagai kesibukan. Total skor yang diperoleh dari 10 responden pada pertanyaan nomor 7 yaitu: $25 / 30 \times 100=83,3 \%$ sehingga interpretasi nilainya tergolong tinggi. Karena pada saat penyuluhan hamper seluruh anggota terlibat dalam kegiatan penyuluhan.

h. Keaktifan dalam Memberikan Iuran Wajib

Keaktifan dalam hal ini adalah seberapa sering anggota memberikan iuran wajib sebesar Rp5.000 hingga Rp7.000 yang dikumpul 2 kali dalam sebulan, yang dipakai untuk berbagai kegiatan kelompok seperti pembelian pupuk, racun untuk tanaman namun dalam penelitian ini diukur selama setahun, keaktifan dalam memberikan iuran wajib dapat dilihat pada Tabel 13.

\begin{tabular}{|c|c|c|c|c|c|}
\hline$\overline{\mathrm{N}}$ & $\begin{array}{c}\text { Tnglat } \\
\text { Pariipasi }\end{array}$ & $\begin{array}{c}\text { Alteratif } \\
\text { ika }\end{array}$ & $\begin{array}{c}\text { Felit Respooden } \\
\text { (Oter) }\end{array}$ & $\begin{array}{c}\text { Perventulue } \\
\text { (9) }\end{array}$ & $\begin{array}{l}\text { Total } \\
\text { itor }\end{array}$ \\
\hline 1 & Sings Ahif & 3 & - & - & - \\
\hline 2 & Aleif & 2 & 7 & 70,00 & 14 \\
\hline \multirow[t]{2}{*}{3} & Kanes Altif & 1 & 3 & 3050 & 3 \\
\hline & helin & & 10 & 100 & 17 \\
\hline
\end{tabular}

Hasil penelitian ini menunjukkan bahwa $70 \%$ memilih aktif adalah anggota kurang mengumpulkan iuran untuk menunjang kegiatan kelompok tani, 30\% memilih kurang aktif adalah anggota yang sibuk dengan berbagai kesibukan lainnya. Total skor yang diperoleh dari 10 responden pada pertanyaan nomor 8 yaitu: $17 / 30 \times 100=$ $56,6 \%$ sehingga interpretasi nilainya tergolong cukup.

\section{Partisipasi Anggota Pada Tahap Evaluasi Kegiatan dalam Kelompok Tani Mitra Jaya}

Partisipasi evaluasi kegiatan kelompok tani Mitra Jaya yaitu memantau kegiatan kelompok dan mengukur berbagai hasil kegiatan usaha tani yang telah dilakukan. Evaluasi yang dilakukan yaitu bermusyawarah mengenai berbagai kekurangan. Selain itu kelompok tani Mitra Jaya juga berusaha meningkatkan kualitas usaha tani yang dilaksanakannya. Dalam penelitian partisipasi dalam tahap evaluasi 2 sub indikator yang diukur yaitu, keterlibatan dalam pemantauan kegiatan kelompok dan keterlibatan dalam mengukur berbagai hasil kegiatan usaha tani. i. Keterlibatan dalam Pemantauan Kegiatan Kelompok

Keterlibatan dalam hal ini adalah seberapa sering anggota terlibat dalam tahap pemantauan kegiatan kelompok, dalam hal ini bukan hanya sekedar memantau tetapi juga berperan aktif dalam berbagai kegiatan kelompok. Keterlibatan dalam pemantauan kegiatan kelompok dalam penelitian ini diukur dalam setahun, dapat dilihat pada Tabel 14.

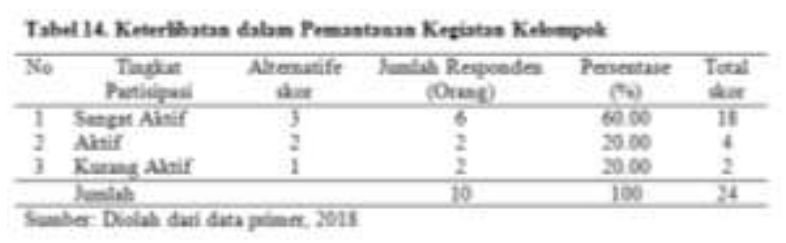

Hasil penelitian ini menunjukkan bahwa $60 \%$ memilih sangat aktif adalah anggota yang memiliki tugas sebagai pengurus kelompok dan selalu terlibat dalam memberikan masukan dalam memantau kegiatan kelompok untuk kesejahteraan anggota dalam meningkatkan hasil panen serta pendapatan anggota, $20 \%$ memilih aktif adalah anggota yang berpengalaman dalam pemantauan kegiatan kelompok, $20 \%$ memilih kurang aktif adalah anggota yang kurang berpengalamn dalam pemantauan kegiatan kelompok. Angka indeks partisipasi mengenai pertanyaan nomor 9 yaitu: $24 / 30$ x $100=80,0 \%$ sehingga interpretasi nilainya tergolong tinggi. Karena anggota sangat aktif dalam memantau kegiatan kelompok.

j. Keterlibatan dalam Mengukur Berbagai Hasil Kegiatan Usaha Tani

Keterlibatan dalam hal ini adalah seberapa sering anggota terlibat dalam tahap mengukur berbagai hasil kegiatan usaha tani dalam hal ini bukan saja mengukur tatapi juga berperan aktif dalam pemanfaatan berbagai hasil kegiatan usaha tani untuk kebutuhan sehari-hari. Keterlibatan dalam mengukur berbagai hasil kegiatan usaha tani dapa dilihat pada Tabel 15.

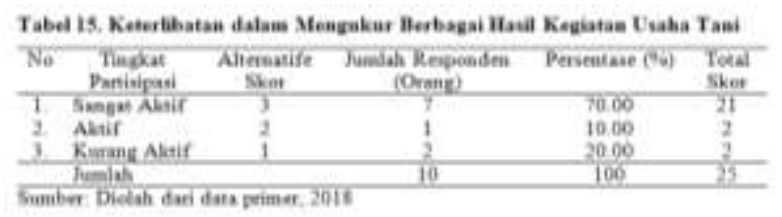

Hasil penelitian ini menunjukkan bahwa $70 \%$ memilih sangat aktif adalah anggota yang ingin mengetahui apa saja yang dicapai dalam usaha tani dan terlibat dalam memberikan masukan karena merupakan petani berpengalaman, $10 \%$ memilih aktif adalah anggota yang berpengalaman dalam kegiatan usaha tani, 20\% memilih kurang aktif adalah anggota yang kurang berpengalaman dalam kegiatan usaha tani dan memiliki berbagai kesibukan lainnya. Angka indeks partisipasi mengenai pertanyaan nomor 10 yaitu: $25 / 30$ x $100=83,3 \%$ sehingga interpretasi nilainya tergolong tinggi. Karena anggota sangat aktif dalam mengukur berbagai hasil kegiatan usaha tani. 


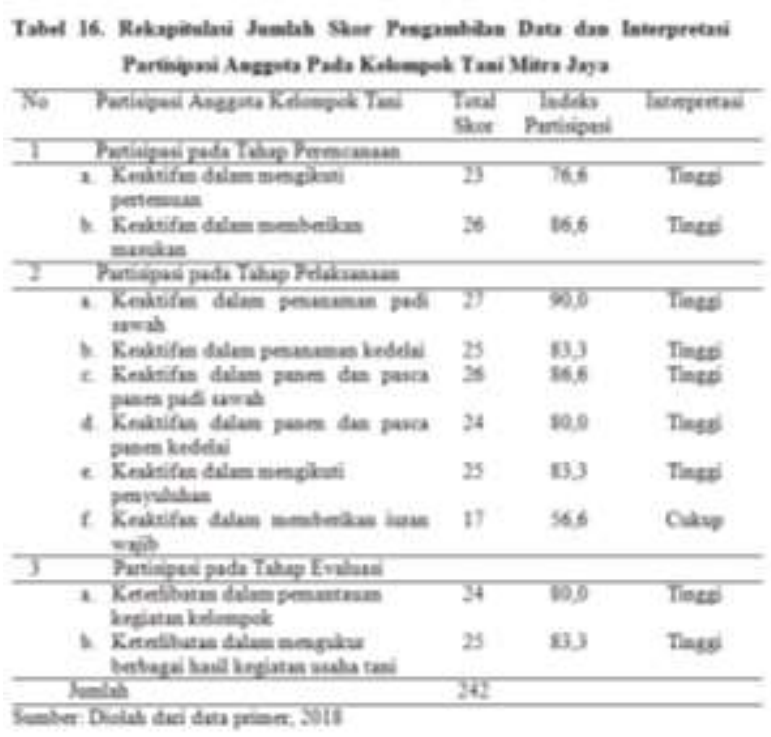

Tabel 16 menunjukkan bahwa terdapat 10 indikator partisipasi anggota pada kelompok tani Mitra Jaya, dimana pertanyaan ke 3 mendapat indeks tertinggi yaitu 90,0\% karena anggota kelompok tani Mitra Jaya sangat aktif pada setiap penanaman padi sawah, sedangkan pertanyaan nomor 1 mendapat indeks partisipasi $76,6 \%$, pertanyaan nomor ke 2 mendapat indeks partisipasi 86,6\%, pertanyaan nomor ke 3 mendapat indeks partisipasi $90,0 \%$, pertanyaan nomor ke 4 mendapat indeks partisipasi $83,3 \%$, pertanyaan nomor ke 5 mendapat indeks partisipasi $86,6 \%$, pertanyaan nomor ke 6 mendapat indeks partisipasi $80,0 \%$, pertanyaan nomor ke 7 mendapat indeks partisipasi $83,3 \%$, pertanyaan nomor ke 8 mendapat indeks partisipasi 56,6\%, pertanyaan nomor ke 9 mendapat indeks partisipasi $80,0 \%$, pertanyaan nomor ke 10 mendapat indeks partisipasi 83,3\% hampir semuanya mendapat interpretasi tinggi. Pertanyaan ke 8 mendapat interpretasi cukup karena berada di 56,6\%. Dan pertanyaan 1,2,3,4,5,6,7,9,10 mendapat interpretasi tinggi karena berada di atas $66,6 \%$. Untuk mengetahui partisipasi anggota pada kelompok tani Mitra Jaya di Desa Mundung maka perlu dihitung jumlah keseluruhan skor mencapai 242. Pada penelitian ini jumlah skor ideal atau skor tertinggi yaitu 300 dan jumlah skor terendah adalah 100. Dari data yang dihimpun sebanyak 10 pertanyaan yang diajukan kepada 10 responden maka diperoleh total skor 242. Total skor, indeks partisipasi dan tingkat partisipasi, perhitungan skor keseluruhan untuk mengetahui partisipasi anggota pada kegiatan kelompok tani Mitra Jaya di Desa Mundung Kecamatan Tombatu Timur, sebagai berikut:

Tingleat Partisipasi Anggota $=\frac{242}{300} \times 100 \%=80,6 \%$

Berdasarkan hasil analisis menggunakan skala likert maka dapat diketahui bahwa angka indeks partisipasi anggota pada kelompok tani Mitra Jaya berada pada titik $80,6 \%$ dan tergolong tinggi.
Kesimpulan secara keseluruhan dari penelitian ini tergambar dalam rekapitulasi jumlah skor partisipasi anggota pada kelompok tani Mitra Jaya. Partisipasi pada kegiatan lainnya semuanya tergolong tinggi. Kecuali keaktifan dalam memberikan iuran wajib yang tergolong cukup, dikarenakan kurang member iuran wajib.

\section{KESIMPULAN DAN SARAN}

\section{Kesimpulan}

Partisipasi anggota pada kelompok tani tergolong tinggi, karena mereka ikut serta dalam setiap kegiatan yang diadakan oleh kelompok tani Mitra Jaya pada tahap perencanaan, tahap pelaksanaan dan tahap evaluasi kegiatan kelompok tani. Partisipasi anggota pada kelompok tani Mitra Jaya di Desa Mundung Kecamatan Tombatu Timur tergolong tinggi.

\section{Saran}

Bagi Pemerintah, masyarakat setempat maupun kelompok tani Mitra Jaya agar lebih meningkatkan partisipasi anggota yaitu keaktifan dalam memberikan iuran wajib karena hal tersebut dapat membantu kesejahteraan dan kepentingan dalam usaha tani kelompok tani Mitra Jaya di Desa Mundung Kecamatan Tombatu Timur.

\section{DAFTAR PUSTAKA}

Amanah, S. dan N. Farmayanti. 2014. Pemberdayaan Sosial Petani-Nelayan, Keunikan Agroekosistem dan Daya Saing. Penerbit Yayasan Pustaka Obor Indonesia. Jakarta.

Nuryanti, S dan Dewa K.S. Swastika. 2011. Peran Kelompok Tani dalam Penerapan TeknologiPertanian. http:// pse.litbang. deptan. go. Id /ind/ pdffiles /FAE29-2d. Pdf. Diakses pada 14 Maret 2018.

Pane, Y. E. 2017. "Hubungan Partisipasi Anggota Dengan Kinerja Kelompok Tani.” Jurnal. Fakultas Sosial dan Ilmu Politik, Universitas Lampung.

Pentury, E. F. 2016. "Partisipasi Anggota Pada Kelompok Tani Susuripen di Kelurahan Wailan Kecamatan Tomohon Utara Kota Tomohon". Jurnal. Universitas Sam Ratulangi. 